\title{
Ekosistem dalam Puisi Membaca Tanda-Tanda Karya Taufiq Ismail Sebuah Kajian Etis Ekokritik
}

\author{
Arianty Visiaty ${ }^{1}$, Zuriyati ${ }^{1}$, Saifur Rohman ${ }^{1}$ \\ ${ }^{1}$ Program Studi Ilmu Pendidikan Bahasa, Pasca Sarjana Universitas Negeri Jakarta, \\ Jl. Rawamangun Muka, Jakarta Timur 13220 \\ Penulis untuk Korespondensi/E-mail: ariantyvisiaty_pb19s3@mahasiswa.unj.ac.id
}

\begin{abstract}
Abstrak - Kerusakan lingkungan merupakan masalah yang penting untuk diperhatikan. Kerusakan lingkungan dapat terjadi karena keseimbangan ekosistem terganggu. Salah satu media untuk menyampaikan isu dan pesan terhadap lingkungan adalah karya sastra. Tujuan penelitian ini adalah untuk mengkaji sastra dari kajian etis ekokritis terhadap puisi karya Taufiq Ismail berjudul "Membaca Tanda-tanda". Metode yang digunakan pada penelitian ini adalah deskriptif kualitatif. Hasil dari penelitian ini adalah terdapat tiga sikap terhadap alam dalam puisi "Membaca Tandatanda", yaitu, sikap solidaritas terhadap alam, sikap kasih sayang dan kepedulian terhadap alam, serta sikap tidak mengganggu kehidupan alam. Kesimpulan dalam penelitian ini adalah, melalui kajian etis ekokritik puisi "Membaca Tanda-tanda" karya Taufiq Ismail ini dapat terlihat gambaran kerusakan alam akibat rusaknya ekosistem karena ulah manusia dan sikap manusia yang ditimbul terhadap fenomena alam tersebut.
\end{abstract}

Abstract - Environmental damage is an important issue for concern. Environmental damage can occur because the balance of the ecosystem is disturbed. One of the media to convey issues and messages to the environment is literature. This research examines literature from an ecocritical ethical study of a poem by Taufiq Ismail entitled "Membaca Tanda-tanda." The method used in this research is descriptive qualitative. This research shows that there are three attitudes towards nature in the poem "Membaca Tanda-tanda": (1) an attitude of solidarity towards the environment; (2) an attitude of love and concern for nature; and (3) an attitude of not interfering with natural life. The conclusion of this research is, through the ethical study of the ecocritical poetry of Taufiq Ismail's poem "Membaca Tanda-tanda", there is a picture of natural damage due to damage to ecosystems caused by human activities and attitudes arising against these natural phenomena.

Keywords - Environment, ecosystem, ecocriticism, poem

\section{PENDAHULUAN}

$\mathrm{K}$ erusakan lingkungan akhir-akhir ini menjadi isu yang hangat di dunia. Kerusakan lingkungan dapat disebabkan karena dua hal, yaitu kerusakan lingkungan karena alam dan karena manusia. Faktor alam misalnya, gempa bumi, gunung meletus, tsunami dll. Faktor manusia misalnya penebangan hutan liar, pencemaran sungai, dll. Kerusakan lingkungan yang disebabkan oleh manusia menyebabkan terjadinya pemanasan global. Dampak pemanasan global sudah sangat dirasakan akhir-akhir ini diantaranya adalah mulai mencairnya gletser, yang menyebabkan permukaan air laut meningkat, perubahan iklim yang tidak dapat diprediksi kembali, kekeringan, kebakaran hutan, dll, curah hujan yang berlebih yang menimbulkan banjir, dll. Kerusakan lingkungan dapat menyebabkan keseimbangan ekologi atau ekosistem. Ekologi sendiri berasal dari kata Yunani, yaitu oikos ("habitat") dan logos ("ilmu"). Ekologi diartikan sebagai ilmu yang mempelajari interaksi antar makhluk hidup maupun interaksi antara makhluk hidup dan lingkungannya. Sedangkan sistem ekologi yang terkait hubungan timbal balik antara mahluk hidup dan lingkungannya disebut dengan ekosistem. Misalnya akibat penebangan hutan secara liar oleh manusia, maka terjadi kekeringan yang menyebabkan kebakaran hutan, kebakaran hutan menyebabkan pemanasan global semakin meningkat, yang menimbulkan lebih banyak kekeringan, sehingga 
banyak daerah yang tidak bisa menghasilkan bahan pangan, yang menyebabkan kelaparan pada umat manusia. Untuk menyelamatkan dunia dan mahluk hidup di dalamnya termasuk manusia maka, manusia sebagai mahluk yang berakal dan bagian dari alam harus mempertahankan keseimbangan ekologi atau ekosistem, dengan menjaga alam.

Kesadaran menjaga alam perlu ditumbuhkan di dalam diri manusia. Dalam rangka menjaga lingkungan sastra merupakan salah satu media yang dapat digunakan untuk menyampaikan pesan-pesan atau gagasan-gagasan terkait lingkungan. Banyak karya sastra yang berhubungan dengan alam, baik itu puisi, prosa, lagu dll.

Terkait dengan hubungan sastra dan alam yang begitu erat, para kritikus sastra mencoba mengkaji karya sastra dari sudut pandang sebuah konsep yang disebut dengan ekokritik, atau disebut juga dengan ecocriticism.

Kata ekokritik berasal dari bahasa Inggris yaitu ecocriticism. Ecocritism berasal dari dua kata, yaitu ecology dan critic. Seperti yang telah disebutkan sebelumnya ekologi adalah ilmu yang mempelajari baik interaksi antar makhluk hidup maupun interaksi antara makhluk hidup dan lingkungannya, sedangkan kritik adalah tanggapan, kadang-kadang disertai uraian dan pertimbangan baik buruk terhadap suatu hasil karya, pendapat, dsb. Sehingga Menurut Glotfelty (1996), Ekokritik sastra adalah studi tentang hubungan antara sastra dan lingkungan fisik [1]. Karya sastra berkembang di lingkungan masyarakat dan lingkungan alam, oleh karena itu karya sastra mempunyai kemampuan untuk memunculkan gagasan tentang lingkungan, termasuk nilai-nilai kearifan yang terkait dengan lingkungan tersebut. Karya sastra merupakan produk kreatif alam dimana manusia menjadi bagian yang tak terpisahkan di dalamnya, sehingga pesan-pesan kearifan yang terkandung di dalam karya sastra dapat menjangkau di keseluruhan kehidupan alam semesta [2].

Salah satu pengarang puisi yang sering membuat puisi bertemakan alam adalah Taufiq Ismail. Di antara puisi karya Taufiq Ismail yang bertemakan alam adalah puisi yang berjudul "Membaca Tandatanda". Puisi ini bertemakan kerusakan alam akibat ulah manusia. Puisi bertemakan alam seperti ini dapat dikaji dengan kajian ekokritik, untuk melihat pesan-pesan moral mengenai pentingnya menjaga ekosistem.
Penelitian ini bertujuan untuk sikap manusia terhadap alam yang terkait dengan fenomena alam yang terkait ekosistem melalui kajian etis ekokritik pada puisi "Membaca Tanda-tanda", karya Taufiq Ismail.

\section{Kajian Ekokritik}

Cheryll Glofelty (1996) dalam bukunya yang berjudul The Ecocriticism Reader: Landmarks in Literary Ecology mendefinisikan ekokritik sebagai studi tentang hubungan antara sastra dan lingkungan fisik [1].

Kajian ekokritik sendiri dapat dibagi menjadi dua. Pertama, kajian yang mengkonstruksi paras sastra (kearifan) lingkungan dan kajian yang melihat segi etis. Kajian yang memfokuskan pada sudut pandang etis ini mendeskripsikan nilai-nilai kearifan lingkungan terhadap lingkungan [2].

Kajian yang mengkonstruksi paras sastra (kearifan) lingkungan mempunyai ciri berfokus pada narasi pastoral dan narasi apokaliptik. Sedangkan kajian yang berfokus pada etis mempunyai ciri mengkaji enam sikap berikut ini [2]:

1. Sikap hormat terhadap alam

2. Sikap tanggung jawab moral terhadap alam

3. Sikap solidaritas terhadap alam

4. Sikap kasih sayang dan kepedulian terhadap alam

5. Sikap tidak mengganggu kehidupan alam

Pastoral bermakna pelarian dari kota ke desa. Pastoral dapat dikatakan sebagai karya sastra yang mendeskripsikan desa dengan mengontraskannya secara implisit dan eksplisit dengan kota. Sehingga dapat dikatakan bahwa narasi pastoral adalah narasi yang menggambarkan desa yang sebenarnya adalah bentuk kontras dari kota.

Sedangkan narasi apokaliptik merupakan narasi yang lahir dari sebuah krisis yang dibuat untuk memperkuat suatu keinginan yang kuat dari komunitas yang terpinggirkan dengan memberikan harapan dan visi kebebasan dari keterbelengguannya [2].

Pastoral terdiri dari:

1. Bucolic. Bucolic berarti "pengembala". Bucolic merupakan sebuah gambaran dari lingkungan desa.

2. Arcadiaya. Arcadiaya adalah gambaran cara hidup dan tempat yang ideal. Arcadiaya terdiri dari tiga unsur, yaitu, 1) Idylls atau diskripsi nilai-nilai ideal dari sebuah desa, dan kritik 
terhadap nilai-nilai kota, 2) Nostalgia, gambaran yang mencerminkan sikap selalu melihat ke masa lalu, dan 3) Georgic yang merupakan gambaran kenyamanan bekerja secara harmonis dengan alam.

3. Retreat dan return. Retreat adalah gambaran pelarian diri dari kompleksitas kota [3]. Sedangkan Return merupakan gambaran pelarian diri dari kota ke desa berupa kesadaran bahwa lingkungan alam seperti pedesaan, hutan, dan gunung dapat memberikan ketenangan dan pengayoman [4].

Model kajian etis meliputi etiket lingkungan atau (nilai) kearifan lingkungan. Etiket merupakan nilai dan prinsip moral yang dianut oleh masyarakat tertentu sebagai pedoman dan kriteria dalam berperilaku manusia [2]. Kajian etis ini tediri dari sikap hormat terhadap alam, sikap tanggung jawab terhadap alam, sikap solidaritas terhadap alam, sikap kasih sayang dan kepedulian terhadap alam, sikap tidak mengganggu kehidupan alam dalam karya sastra. Pada penelitian ini puisi karya Taufiq Ismail yang berjudul "Membaca Tanda-tanda" akan dikaji dengan pendekatan ekokritik model kajian etis.

\section{Ekosistem}

Menurut Undang-undang Republik Indonesia No, 32 tahun 2009 tentang perlindungan dan pengelolaan lingkungan hidup, ekosistem adalah tatanan unsur lingkungan hidup yang merupakan kesatuan utuh-menyeluruh dan saling mempengaruhi dalam membentuk keseimbangan, stabilitas, dan produktivitas lingkungan hidup. Ekosistem meliputi seluruh mahluk hidup termasuk manusia, hewan, tumbuhan, dan orgasme lainnya yang berinteraksi satu sama lain, termasuk dengan benda yang tidak hidup seperti, bumi, cuaca, iklim, atmosfer, dll. Sehingga secara sederhana dapat dikatakan ekosistem adalah hubungan timbal balik antar unsur lingkungan yang membentuk keseimbangan, termasuk hubungan antar manusia dengan alam.

Menjaga ekosistem sangat penting untuk menjaga keharmonisan hubungan antara manusia dan alam. Bencana alam yang terjadi akhir-akhir ini banyak yang terjadi karena rusaknya ekosistem akibat ulah manusia. Manusia merusak alam, sehingga alam menjadi tidak seimbang dan menimbulkan bencana. Bencana alam ini pada akhirnya akan merugikan manusia juga, seperti yang telah dicontohkan pada bagian pendahuluan.

\section{Taufiq Ismail}

Taufiq Ismail adalah seorang penyair dan sastrawan yang lahir di Bukit Tinggi, Sumatra Barat, 25 Juni 1935. Taufiq Ismail pertama kali menerbitkan puisinya dalam kumpulan puisi yang berjudul Tirani dan Benteng pada tahun 1966. Kumpulan puisi ini bertema demonstrasi. Setelah itu terbitlah puisi-puisi karnyanya yang lain. Atas karyakaryanya yang berkualitas, Taufiq Ismail telah mendapat berbagai penghargaan baik dari dalam dan luar negeri, dan beberapa puisinya telah diterjemahkan ke berbagai bahasa di antaranya Inggris, Prancis, Jerman, Rusia, dan Cina.

Selain bertema politik, puisi-puisi Taufiq Ismail banyak yang bertemakan alam di antaranya adalah puisi "Membaca Tanda-tanda" yang bertema kerusakan alam. Puisi ini merupakan bagian dari kumpulan puisi berjudul "Puisi-puisi Langit". Puisi dala kumpulan puisi "Puisi-puisi langit" banyak bertemakan alam dan berkontribusi dalam pendidikan terutama terkait isu-isu ekologi [5]. Penelitia ini memfokuskan pada puisi "Membaca Tanda-tanda", sebagaimana tertera di bawah ini.

Alam Bergejolak

Ada sesuatu yang rasanya mulai lepas dari tangan

dan meluncur lewat sela-sela jari kita

Ada sesuatu yang mulanya tidak begitu jelas tapi kita kini mulai merindukannya

Kita saksikan udara abu-abu warnanya

Kita saksikan air danau yang semakin surut jadinya

Burung-burung kecil tak lagi berkicau pergi hari

Hutan kehilangan ranting

Ranting kehilangan daun

Daun kehilangan dahan

Dahan kehilangan hutan

Kita saksikan zat asam didesak asam arang dan karbon dioksida itu menggilas paru-paru

Kita saksikan

Gunung membawa abu

Abu membawa batu

Batu membawa lindu

Lindu membawa longsor

Longsor membawa air

Air membawa banjir

Banjir air mata 
Kita telah saksikan seribu tanda-tanda

Bisakah kita membaca tanda-tanda?
Allah
Kami telah membaca gempa
Kami telah disapu banjir
Kami telah dihalau api dan hama
Kami telah dihujani api dan batu
Allah
Ampunilah dosa-dosa kami

\section{Beri kami kearifan membaca tanda-tanda \\ Karena ada sesuatu yang rasanya mulai lepas dari tangan \\ akan meluncur lewat sela-sela jari}

Karena ada sesuatu yang mulanya tak begitu jelas

tapi kini kami mulai merindukannya

\section{(Taufiq Ismail, Membaca Tanda-Tanda)}

Penelitian kajian ekokritik sastra telah banyak dilakukan baik dalam karya sastra novel, puisi, dongeng, dll. Untuk penelitian yang berfokus pada karya sastra puisi di antaranya adalah penelitian Aris (2020) dan Sultoni (2020). Aris (2020) mengkaji puisi "Talang di Langit Falastin" karya Dheni Kurnia. Berdasarkan hasil penelitian ini diketahui bahwa puisi ini menggambarkan eksploitasi lingkungan yang mengakibatkan kerusakan alam. Puisi ini juga menggambarkan keporakporandaan lingkungan Palestina akibat polusi yang dihasilkan oleh senjata nuklir atau sejenisnya [6]. Sedangkan Sultoni (2020) mengkaji Buku Puisi "Air Mata Manggar" Karya Arif Hidayat. Hasil penelitian ini menunjukan tiga bentuk kritik ekologis, yaitu, kritik terhadap persoalan alih fungsi lahan, kritik terhadap persoalan pencemaran lingkungan, dan kritik terhadap persoalan perubahan iklim [7]. Hasil kedua penelitian terhadap puisi ini memunculkan makna kerusakan lingkungan akibat ulah manusia yang tersimpan di balik puisi. Hasil penelitian ini juga menunjukan pentingnya untuk menjaga lingkungan atau hidup harmonis dengan lingkungan.

Penelitian berfokus pada puisi-puisi karya Taufiq Ismail yang terkait dengan alam, telah dilakukan oleh Setyorini \& Irma (2018), dan Sumaryati \& Helmi (2019). Setyorini \& Irma (2018) melakukan kajian representasi krisis ekologi pada karya puisi
Taufiq Ismail yang berjudul "Membaca Tandatanda" dan "Menengadah ke Atas Merenungi Ozon yang Tak Tampak". Hasil dari penelitian ini adalah, pertama Puisi "Membaca Tanda-tanda" merepresentasikan krisis ekologi yang ada di Indonesia, seperti pencemaran udara, hutan gundul, dan efek rumah kaca, kedua, puisi "Menengadah Ke Atas Merenungi Ozon Yang Tak Nampak" merepresentasikan krisis ekologi di Indonesia, seperti: pencemaran sungai, danau, dan kebakaran hutan [8].

Sumaryati \& Helmi (2019) menelaah kumpulan puisi karya Taufiq Ismail yang berjudul "Puisi-puisi Langit". Penelitian ini menunjukan kritik perlunya kehidupan yang harmonis antara manusia dan mahluk hidup lainnya, serta perlunya kerjasama sesama manusia untuk menjaga alam. Selain itu penelitian ini juga memperlihatkan kritik terkait isu-isu lingkungan baik isu lokal, nasional, maupun global, dan manusia yang tidak peduli akan lingkungan [5].

Kedua penelitian dengan data karya puisi Taufiq Ismail ini, sama-sama menfokuskan pada kajian ekologi, akan tetapi tidak menelaah dari sudut pandang kajian etis ekokritik. Penelitian ini berfokus pada satu puisi karya Taufiq Ismail yang berjudul "Membaca Tanda-tanda" dengan menelaah karya tersebut berdasarkan kajian etis ekokritik.

\section{METODE}

Penelitian ini merupakan penelitian merupakan penelitian kualitatif yang menggunakan metode penelitian deskriptif-kualitatif, dengan sumber berupa puisi karya Taufiq Ismail yang terkait dengan alam, yaitu puisi yang berjudul "Membaca Tanda-tanda". Tahapan penelitian ini adalah sebagai berikut:

1. Membaca puisi "Membaca Tanda-tanda" karya Taufiq Ismail dengan detil dan teliti, untuk mencari data yang terkait dengan kajian etis ekokritik.

2. Memilah data yang terkait dengan kajian etis ekokritik kemudian memisahkan data yang tidak terkait.

3. Mengkategorikan jenis sikap yang terkait kajian etis ekokritik, yaitu, sikap hormat terhadap alam, sikap tanggung jawab terhadap alam, sikap solidaritas terhadap alam, sikap kasih sayang dan kepedulian terhadap alam, sikap 
tidak mengganggu kehidupan alam dan mengkaitkan dengan ekosistem.

4. Menganalisis dengan melakukan pembacaan kritis dan memberikan makna terkait sikap dalam kajian etis ekokritik.

5. Menarik kesimpulan.

\section{HASIL DAN PEMBAHASAN}

Sikap terhadap yang terlihat pada puisi "Membaca Tanda-tanda" karya Taufiq Ismail adalah sikap solidaritas terhadap alam, sikap kasih sayang dan kepedulian terhadap alam, serta sikap tidak mengganggu kehidupan alam. Hasil ini dapat dilihat pada Tabel 1:

Tabel 1. Sikap Terhadap Alam pada Puisi "Membaca Tanda-Tanda" Karya Taufik Ismail

\begin{tabular}{cl}
\hline Sikap & \multicolumn{1}{c}{ Bait Puisi } \\
\hline Sikap & Allah \\
Solidaritas & Kami telah membaca gempa \\
Terhadap & Kami telah disapu banjir \\
Alam & Kami telah dihalau api dan hama \\
& Kami telah dihujani api dan batu \\
\hline & Ada sesuatu yang mulanya tidak \\
& begitu jelas \\
tapi kita kini mulai merindukannya \\
\cline { 2 - 2 } Sikap Kasih & Karena ada sesuatu yang mulanya \\
Sayang dan & tak begitu jelas \\
Kepedulian & tapi kini kami mulai merindukannya \\
\cline { 2 - 2 } Terhadap & Kita telah saksikan seribu tanda- \\
Alam & tanda \\
& Bisakah kita membaca tanda-tanda? \\
\cline { 2 - 2 } & Beri kami kearifan membaca tanda- \\
& tanda \\
\hline & Hutan kehilangan ranting \\
& Ranting kehilangan daun \\
& Daun kehilangan dahan \\
Dahan kehilangan hutan \\
\cline { 2 - 2 } Sikap Tidak & Kita saksikan \\
Mengganggu & Gunung membawa abu \\
Kehidupan & Abu membawa batu \\
Alam & Batu membawa lindu \\
& Lindu membawa longsor \\
& Longsor membawa air \\
& Air membawa banjir \\
& Banjir air mata \\
\hline a 1 Tap Alam
\end{tabular}

Sikap Solidaritas Terhadap Alam

Sikap solidaritas terhadap alam, dapat terlihat pada kutipan puisi Membaca Tanda-tanda berikut.

\footnotetext{
Allah

Kami telah membaca gempa

Kami telah disapu banjir

Kami telah dihalau api dan hama

Kami telah dihujani api dan batu
}

Pada kutipan puisi di atas terlihat bahwa manusia telah merasakan amukan alam yang menyebabkan kerusakan alam. Kutipan di atas menunjukan bahwan manusia telah bertubi-tubi ditimpa bencana, bencana gempa, bencana banjir, kebakaran, hama pada hutan dan tumbuhtumbuhan, dan bencana hujan api yang bisa dimaknai dengan kemarau panjang, dan batu yang dimaknai dengan hujan batu es yang ekstrim. Kalimat pasif yang ditandai dengan kata /disapu/, /dihalaul, Idihujanil, menunjukan bahwa manusia telah merasakan akibat dari kemarahan alam dan manusia hanya bisa pasif tidak bisa berbuat apaapa. Ketika alam sudah murka, maka alam bisa malakukan apa saja yang akhirnya merugikan manusia itu sendiri. Kutipan ini menunjukan kepasrahan manusia setelah ditimpa musibah kemarahan alam yang merupakan ulah manusia sendiri. Kepasrahan ini merupakan bentuk kesadaran manusia, bahwa derajat manusia tidaklah lebih tinggi dari derajat alam. Manusia bukan penguasa alam yang bisa seenaknya memanfaatkan alam untuk kepentingannya, tanpa memperhatikan kebutuhan alam itu sendiri. Manusia adalah bagian dari alam, dan tidak lebih tinggi dari alam, serta merupakan bagian dari ekosistem. Manusia dan alam saling bergantung dan mempengaruhi satu sama lain. Manusia setelah ditempa bencana mulai merasakan akibat ulahnya dan mulai merasakan bahwa ia bagian dari alam, tidak lebih tinggi dari alam, oleh karenanya manusia harus menghargai alam. Sebagai bagian integral dari alam semesta manusia mempunyai kedudukan yang sama dengan alam dan dengan sesama mahluk hidup lainnya. Dengan adanya bencana manusia telah merasakan rasa sakit yang sama ketika manusia merusak alam, hal ini menimbulkan rasa solider manusia terhadap alam, Kutipan puisi di atas menunjukan timbulnya rasa solider manusia setelah merasakan kepedihan akibat bencana, yang sama dirasakan alam ketika manusia merusak alam.

\section{Sikap Kasih Sayang dan Kepedulian Terhadap Alam}

Sikap kasih sayang dan kepedulian terhadap alam terlihat pada kutipan puisi "Membaca Tanda-tanda" berikut.

\section{Ada sesuatu yang mulanya tidak begitu jelas \\ tapi kita kini mulai merindukannya}

Kutipan puisi yang sama muncul kembali di bagian akhir puisi, yaitu: 
Karena ada sesuatu yang mulanya tak begitu jelas

tapi kini kami mulai merindukannya

Sikap kasih sayang dan kepedulian terhadap alam di atas terlihat pada kalimat /kami mulai merindukannyal. Inyal di dua bait puisi ini menunjukan pada alam. Setelah berbagai bencana alam yang menimbulkan kerusakan alam dan berefek pada manusia kembali, manusia mulai merindukan kembalinya alam yang seperti dulu. Manusia merindukan Kembali hubungan dengan alam yang harmonis. Akibat ego dan nafsu manusia, manusia terus mengekploitasi alam, manusia berbahagia dan hidup dalam kesenangan dengan hasil yang didapatnya dengan mengeksploitasi alam. Hal ini menyebabkan manusia buta, dan tidak melihat penderitaan alam. Setelah alam menjadi rusak, dan timbul bencana yang merugikan manusia, manusia mulai menyadari pentingnya alam. Manusia mulai merindukan alam yang dulu, yang bersih, indah, yang di dalamnya ia hidup harmonis dengan alam. Kalimat /kami mulai merindukannya/ menunjukan bahwa mulai tumbuh rasa kasih sayang dan kepedulian manusia terhadap alam. Manusia ingin mendekatkan dirinya kembali kepada alam dan menciptakan hubungan yang harmonis dengan alam.

Kutipan lain yang terkait sikap kasih sayang dan kepedulian terhadap alam adalah pada bait berikut:

Kita telah saksikan seribu tanda-tanda Bisakah kita membaca tanda-tanda?

Selain itu juga terlihat pada bait berikut.

\section{Beri kami kearifan membaca tanda-tanda}

Kutipan ini menujukan kepedulian manusia terhadap alam. Manusia yang tadinya tidak peduli mulai memperhatikan alam. Banyak tanda-tanda luka, kesedihan dan kemarahan alam akibat ulah manusia, berupa berbagai bencana, akan tetapi selama ini manusia sibuk dengan kepentingan dan egonya sehingga tidak memperhatikan. Kalimat /bisakah kita membaca tanda-tanda?/, dan terutama kalimat /beri kami kearifan membaca tanda-tandal yang merupakan doa manusia kepada tuhan, bemakna kembalinya keinginan manusia untuk melihat tanda-tanda alam. Dengan mengetahui tanda-tanda yang ada di alam, apakah alam sedang terluka, atau apakah memerlukan perhatian manusia, dll, maka manusia akan dapat hidup harmonis dengan alam. Hal ini adalah bagian dari sikap kepedulian dan kasih sayang manusia terhadap alam.

\section{Sikap Tidak Mengganggu Kehidupan Alam}

Sikap tidak mengganggu kehidupan alam, terlihat dalam kutipan puisi "Membaca Tanda-tanda" berikut.

\section{Hutan kehilangan ranting \\ Ranting kehilangan daun \\ Daun kehilangan dahan \\ Dahan kehilangan hutan}

Selain itu, sikap tidak mengganggu kehidupan alam juga terlihat dalam kutipan puisi berikut.

\section{Kita saksikan \\ Gunung membawa abu \\ Abu membawa batu \\ Batu membawa lindu \\ Lindu membawa longsor \\ Longsor membawa air \\ Air membawa banjir \\ Banjir air mata}

Apabila diperhatikan dua bait puisi di atas, maka akan terlihat hubungan timbal balik yang ada di alam atau ekosistem. Segala sesuatu yang ada di alam saling berkaitan. Termasuk manusia dan mahluk hidup lain saling berkaitan dengan alam. Merusak salah satu unsur dari ekosistem berarti merusak seluruh alam. Bila kita telaah kutipan pertama, bila hutan kehilangan rantingnya, maka ranting akan kehilangan daun, bila daun kehilangan dahan, maka dahan akan kehilangan hutan. Hutan berasal dari pohon, pohon ada karena ada dahan, ranting dan daun. Ketika dahan ranting daun kering dan hilang maka, pohon akan kering, maka hutan akan hilang. Demikian juga dengan bait kedua, ketaka gunung api meletus dan mengeluarkan abu, abu bisa menjadi batu, batu bisa menjadikan lindu atau gempa. Gempa bisa membuat tanah menjadi longsor, longsor menyebabkan air dari daerah tinggi mengalir dan membawa banjir, dan akhirnya manusia juga yang merasakan kerugian dan kesedihannya, karena korbannya bisa saja manusia itu sendiri. Dan pada akhirnya kerugian akibat ulah manusia ini menyebabkan manusia menangis sedih mengeluarkan air mata. Sikap yang ingin ditunjukan pada bait-bait di sini adalah sikap tidak menganggu kehidupan alam. Karena seperti yang 
telah dijelaskan sebelumnya semua unsur alam termasuk mahluk hidup dan manusia di semesta ini terkait satu sama lain. Ketika manusia merugikan atau merusak satu unsur maka akan menyebabkan rusaknya ekosistem dan menghancurkan unsur yang lain dan akhirnya merusak manusia itu sendiri yang merupakan bagian dari alam. Oleh karenanya manusia tidak boleh mengganggu alam atau merusak ekosistem. Manusia harus membiarkan alam tidak tersentuh.

\section{KESIMPULAN}

Sikap manusia terhadap alam yang ditemukan pada puisi ini, adalah sikap solidaritas terhadap alam, sikap kasih sayang dan kepedulian terhadap alam, serta sikap tidak mengganggu kehidupan alam. Dari hasil kajian ini maka dapat dilihat hubungan yang mendalam antara puisi "Membaca Tanda-tanda" karya Taufiq Ismail dengan alam, dan juga dapat terlihat pesan-pesan moral yang terkait dengan menjaga alam dan ekosistem. Manusia adalah bagian dari alam dan mempunyai derajat yang sama. Manusia adalah unsur dari alam semesta. Apabila salah satu unsur rusak maka akan merusak seluruh unsur dari alam semesta, termasuk manusia itu sendiri atau dengan kata lain rusaknya ekosistem. Ujung-ujungnya adalah merugikan manusia itu sendiri, untuk itu kita perlu untuk bersolidaritas dengan alam, sayang dan peduli terhadap alam, dan tidak mengganggu alam atau ekosistem.

\section{REFERENSI}

[1] C. Glotfelty and H. Fromm, The Ecocriticism Reader: Landmarks in Literary Ecology. University of Georgia Press, 1996.

[2] S. Sukmawan, Ekokritik Sastra: Menanggap Sasmita Arcadia. Universitas Brawijaya Press, 2016.

[3] T. Gifford, Pastoral. Routledge, 1999.

[4] E. Sulistijani, "Kearifan Lokal dalam Kumpulan Puisi Kidung Cisadane Karya Rini Intama (Kajian Ekokritik Sastra)," Nusa, vol. 13, no. 1, pp. 1-15, 2018.

[5] M. L. A. Sumaryati and M. N. Helmi, "Puisi-puisi Langit by Taufiq Ismail: A Literary Ecology Study," in Proceedings of the 28th International Conference on Literature: "Literature as a Source of Wisdom," 2019, pp. 669-680.

[6] Q. I. Aris, "Ekokritik Sastra Dalam Puisi Talang Di Langit Falastin Karya Dheni Kurnia," J. Ilmu Budaya, vol. 16, no. 2, pp. 98-109, 2020.

[7] A. Sultoni, "Kritik Ekologis dalam Buku Puisi Air Mata Manggar Karya Arif Hidayat: Kajian Ekologi Sastra," JP-BSI (Jurnal Pendidik. Bhs. dan Sastra Indones., vol. 5, no. 1, pp. 6-10, 2020.

[8] C. N. I. Nurul Setyorini, "Representasi Krisis Ekologi di Indonesia Puisi Mambeca Tanda-tanda dan Menengadah ke Atas Merenungi Ozon yang Tak Nampak Karya Taufik Ismail," J. Bahtera, vol. 5, no. 9, pp. 317-329, 2018. 